\title{
China's Footprint in Africa's Peace and Security: The Contending Views
}

\author{
Oita Etyang \\ PhD student; Department of Politics and International Relations, \\ University of Johannesburg, Po Box 524, Auckland Park, 2006 Johannesburg, \\ South Africa \\ reinnyetyang@gmail.com \\ Simon Oswan Panyako \\ PhD student; Institute of Diplomacy and International Relations (IDIS), \\ University of Nairobi, Po Box 30197, oo10o Nairobi, Kenya \\ psoswan@gmail.com
}

\begin{abstract}
China's role in the global peace politics has been transformed in the past two decades. Apart from its dominance in the economic realm, China has placed issues of peace and security at the centre of its foreign policy. In Africa, China has actively engaged in Africa's peace and security agenda from opening a military base in Djibouti to participating and contributing to peace talks in South Sudan. Based on the emerging trends, it would appear that the long-cherished non-interference principle is undergoing a deliberate transformation given the emerging realities in the global geo-politics. It is based on this "paradigmatic shift" that this paper interrogates China's role in Africa's peace and security. The paper argues that China's interest in Africa's peace and security agenda is driven by economic and geo-political interests. The paper further discusses the role that China has played in military cooperation, peacekeeping, conflict resolution and post conflict reconstruction in Africa using specific country case examples.
\end{abstract}

\section{Keywords}

Africa - China - conflict - peace - security 


\section{Introduction}

The geo-political ties based on alliances and cooperation between China and many African countries was cemented by the colonial struggles of 196os and 1970s. During this historical period, China supported many liberation movements in Africa that culminated in the independence of many states. For instance, China was at the forefront in supporting the National Liberation Front of Angola (FN LA), in the Angolan Civil War in 1975. China further successfully supported the victorious liberation struggles in Zimbabwe (Walsh, 2019: 6). With the changing patterns in the geo-politics in the 21st century, China's interest and involvement in Africa affairs has gained momentum and traction as exemplified in the organisation of many joint economic and security forums. Whilst China continued to engage albeit on a bilateral basis with African states after the colonial struggles of the 196os, the bilateral ties changed with the holding of the first Ministerial Conference of the Forum on China-Africa Cooperation (FOCAC), held in 2000 in Beijing. Since this ground-breaking conference, multilateral and bilateral engagements between China and African countries have continued to flourish. China's foreign policy of non-interference has also morphed overtime to safeguard its national interest defined in terms of commercial and security interests.

China's foreign policy objective that is reflective of its national interest stresses that China has worked closely with African countries for the sake of common development, which has been actively promoted as the core of China's foreign policy towards Africa. In this regard, China emphasises its "shared destiny" with Africa, which is amplified by traditional friendship, mutual political trust, practical cooperation in many areas and coordination and cooperation in international affairs. As far as mutual benefits are concerned, China's contemporary foreign policy continues to stress the enormous development opportunities for Africa which stem from China's new development momentum, while an "emerging and rejuvenating Africa" in turn supports China's own development agenda. The Chinese Ambassador in South Africa, Tian Xuejun (2015) for instance views Chinese-African relations as follows:

China and Africa enjoy natural affinity because of similar historical experience and our similar development goals have made us natural partners in the way forward. China and Africa are always good friends, good partners and good brothers sharing wealth and woe.

In other words, China endeavours to be seen as a "good" partner in Africa's development. A good example that augments the strong relations between 
China and African states in recent years relates to the Chinese-financed construction of the African Union ( $\mathrm{AU}$ ) headquarters in Addis Ababa (Gill and Huang, 2013: 152).

China's involvement in Africa's peace and security affairs is grounded on both realist and economic development theories. China is viewed as a rational actor driven by her national interest. It suffices to note that China's involvement in African is for her own survival by gaining power and influence. As (Sun, 2014) postulates, China seeks Africa's support in multilateral organisations and forums to achieve its global agenda, given the fact that African countries represent a significant voting capacity of 54 states, which equals more than a quarter of the United Nations (UN) members. From the realist perspective for instance, Pugh (2004: 50) avers that China is involved in peacekeeping missions to amplify its international influence and power. The international influence and power, therefore, become critical in the pursuit of its interests in the international arena. As such, China uses the platform of international organisations such as the UN to project its influence.

China's interest in peace and security in Africa is further linked to its economic interest in the region. The economic interest primarily stems from the liberal paradigm. The liberal perspective underscores the fact that states engaged in matters of peace and security to serve their own interests. These interests can be defined in terms of preservation of the status quo or for economic gains. Therefore, re-emergence of China as a major power on the world stage and its increased involvement in matters of peace and security can be understood in this context. According to the liberal perspective, China recognises the importance of international cooperation especially in the area of peace and security to its economic development. As Buzan (2010: 12) argued "China put its own economic development as top priority and deduced from that the need for stability in its international relations both regionally and globally".

While much attention has been dedicated to China's economic and infrastructural expansion (see for example, Holz, 2008) a body of scholarship such as Alden (2007), Taylor and Wu (2013) Etyang and Oswan (2016), Barton (2018), Walsh (2019), Alden and Large (2011) and Large (2015) have emerged to address China - Africa security cooperation from different perspectives. The above scholarship notwithstanding, there is still growing interest on ChinaAfrica peace and security agenda. It is based on this growing scholarly interest that this paper seeks to answer three fundamental questions (1) what drives China's interest in Africa's peace and security; (2) to what extent has this interest shaped China's engagement in Africa peace and security; (3) in what areas of peace and security is China involve in? By answering these questions, 
the paper aims at complementing extant scholarship in this subject area. The paper draws upon existing literature - books, journal articles, media and mission reports and policy briefs to build its case. These are supplemented by authors' experiences and engagement with various actors in the field of Africa's peace and security. The paper uses a combination of analytical insights and case studies to answer the above three questions.

Since the turn of the 21st century, Chinese companies - both state and private entities have invested in various countries in Africa. Most of the investments have been in the natural resource and manufacturing sectors. Suffice to mention that China's investments have been geared towards China's strategic objectives, that is, accessing resources and leveraging on China's technological advantage especially in the construction industry. The heavy investments by Chinese companies in Africa have been given impetus by the "Go out" policy that is anchored on leveraging bilateral diplomatic ties with African states to provide and create business opportunities for Chinese firms. According to Barton (2018: 414) the bilateral engagement pegged on commercial expansion has "allowed China to become an economic powerhouse across a host of African commercial sectors and thus on the continent as a whole". In the period 2011-2014 for instance, China's Foreign Direct Investment (FDI) stock grew from USD 491 million to USD 32.4 billion. This significant rise in the FDI stock also impacted on the number of African recipients.

The highest beneficiaries of China's FDI during this period include South Africa, Angola, Democratic Republic of Congo (DRC), Zambia, Zimbabwe, Sudan, Nigeria and Algeria. The heavy investments by China in Africa, has prompted it to engage in issues of peace and security to protect its investments. To China, ensuring peace and security in various regions of Africa provides them an opportunity to safeguard their investments. It is imperative to note that China in most cases has heavily invested in conflict prone regions of the continent such as the Democratic Republic of Congo (DRC) and South Sudan. To maintain its interest in these regions requires strategic involvement in conflict prevention, conflict resolution and post conflict reconstruction initiatives. Through the United Nations Mission in the Republic of South Sudan (UNMISS) for example, China has deployed a combat battalion to protects its interest in the oil fields. South Sudan is considered a critical site of China's oil investment. Hang (2014) and Aguirre (2014) argue that between 2008 and 2013, China had concluded bilateral agreements with the government of South 
Sudan worth US\$ 10 billion. We conclude that the deployment of combat battalion by China to South Sudan is to protect these business deals. The establishment of the Peoples Liberation Army Navy (PLAN) base in Djibouti in August 2017 is also considered part of the larger scheme by China to protect its business interest in the Horn. Melvin (2019: 3-4) argues that the naval base in Djibouti is meant to support China's economic interests in the Horn and conducting naval diplomacy. The base plays a significant role in ensuring that China's vision of a maritime sea route which is in line with its Belt and Road initiative is realised. The development of the naval base is as a result of the financial and commercial ties between China, Djibouti and Ethiopia. The fraternal ties between these three countries have resulted in the construction of the Ethiopia-Djibouti railway, the Ethiopia-Djibouti water line and the development of Doraleh multipurpose port (Melvin, 2019:4). The bilateral and strategic security engagements as highlighted above between China and Djibouti and China and other countries in the continent serve both its economic and security interests.

China's interest in peace and security in Africa is further driven by the desire to protect its trade market and its investments. China's trading volumes have been increasing in the recent past. In 2017, it is estimated that the bilateral trade volumes between China and Africa were approximately US $\$ 170$ billion. The increased trade volume is attributable to Chinese companies' willingness to invest in regions considered risky or have been neglected by other development partners (Barton, 2018: 414-415). In other words, China through its numerous companies has been able to open up new markets in the continent. In terms of Foreign Direct Investment (FDI), Chinese annual flows to Africa have been increasing over the years. From $2003^{-2018}$ for instance, the FDI inflows grew from US $\$ 75$ million in 2003 to US $\$ 5.4$ billion in 2018 (China Africa Research Initiative, 2019). The top 5 African destinations of Chinese FDI in 2018 were South Africa, Democratic Republic of Congo, Mozambique, Zambia, and Ethiopia (China Africa Research Initiative, 2019). To safeguard the markets and investments, China has been forced to review its foreign policy and actively engage in Africa's peace and security agenda such as peacekeeping initiatives. China is cognisant of the fact that it can only enhance its trade interest in Africa if peace and security is guaranteed. China's top ten trading partners in Africa are summarized in Table 1.

While the percentages indicated in Table 1 below appear insignificant for Democratic Republic of Congo and Sudan not even featuring among the top ten African countries trading with China, it can be argued that China's interest in these two countries is not limited to volumes of trade but geopolitical presence and its investment in key sectors like oil and minerals. 
TABLE 1 China's top ten trading partners in Africa (2016)

\# Country

$\begin{array}{rll}\text { 1. } & \text { South Africa } & 15 \cdot 9 \\ 2 . & \text { Angola } & 12.2 \\ \text { 3. } & \text { Egypt } & 8.6 \\ \text { 4. } & \text { Nigeria } & 8.3 \\ 5 \cdot & \text { Algeria } & 6.2 \\ 6 . & \text { Kenya } & 4.4 \\ 7 . & \text { Tanzania } & 3.0 \\ 8 . & \text { Ethiopia } & 2.8 \\ 9 . & \text { Morocco } & 2.7 \\ \text { 10. } & \text { Democratic Republic of Congo } & 2.4\end{array}$

Percentage of bilateral trade as per the overall China-Africa trade volume (\%)

SOURCE: BARTON (2018: 414)

China's interest in Africa's peace and security agenda is further driven by the desire to position itself strategically in the global arena. By actively engaging in matters of peace and security in the continent, China seeks to boost its image as a peacemaker globally. It seeks to demonstrate to the world that it can be relied upon as a valuable actor in peace and security. As noted by Huang and Gill (2009) "[...] engagement with [Africa] helps China project a more benign and harmonious image beyond its borders [...]" According Huang and Gill (2009), China's involvement in the world's peace and security agenda "reassure neighbours about its peaceful intentions and softly balances US and western influence while gradually but more firmly establishing China's acceptance as a great power."

China's interest is in addition driven by domestic political imperatives to protect its citizen abroad. It is estimated that there are more than 1 million Chinese nationals in the continent engaged in various activities such as mining and trade. The huge number of Chinese and the periodic attacks against Chinese national and business ventures around the continent has forced China to develop strategies to protect its citizens abroad including peacekeeping operations. In DR Congo, 3 Chinese nationals working in a mine in northeastern province of Ituri were killed (Reuters, 2020). In Libya for instance, after the removal of Colonel Muammar Gaddafi from power, it was reported that more than 27 Chinese construction sites had been attacked and looted. During this time, the China State Construction Engineering Corporation reported that 
its constructions projects worth 17.6 billion yuan (US $\$ 2.68$ billion) had been destroyed in Libya due to conflict. The insecurity in some of these countries has compelled China to evacuate its citizen from areas considered warzone (Global Times, 2011). In 2015 for example, China evacuated its nationals and other foreign citizens from strife-torn Yemen (Reuters, 2015). At the height of conflict in Libya, China evacuated more than 29,00o Chinese nationals (China Daily, 2011). Finally, China's involvement in Africa's peace and security provides China with the opportunity to gain practical experience to deal with emerging security threats and challenges in the global world. As noted by Huang and Gill (2009) China's deployment of troops, police and experts in various conflict environment "provide useful and practical experiences for Chinese security forces and help improve their responsiveness, riot control capabilities of military emergency command systems and ability to conduct military operations other than war."

\section{Areas of China's Engagement in Africa Peace and Security}

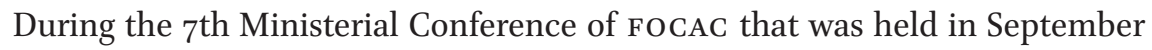
2018, President Xi Jinping delineated the blueprint for China-Africa relations in matters peace and security. In this conference, it was delineated that China will:

- Continue to provide assistance to African countries and organisations through bilateral and multilateral channels.

- Support the African Union (AU) in its independent peacekeeping missions.

- Continue to provide military support to the AU as a way of promoting and enhancing "Africa solution to Africa problems".

- Provide military training opportunities to African countries to enhance their capacities and capabilities in defence, counter terrorism, tackling piracy, human trafficking, cross-border organised crimes, peacekeeping and the general maintenance of peace and security.

- Continue safeguarding and securing trade routes between China and Africa.

- Collectively with African countries implement the fifty-security assistance programme to address growing risks to China's projects such as One Belt One Road (Овов). The fitty-security assistance programme encompasses counterterrorism assistance, law enforcement, strengthening and establishing early warning systems and infrastructure protection (Nantulya, 2019).

The expanding role of China in Africa's peace and security agenda as explicated above aligns with its foreign policy goal to project itself as a responsible great power as alluded to in the introductory section. Becoming a responsible great 
power is part of China's stated policy of "peaceful development," which is China's attempt to reduce fears that China will challenge Western dominance of the current system of global governance. Playing a greater role in peace and security is part of this role and is a clear example of China's attempts to increase its involvement in global affairs within the current system and often in partnership with established actors. We explore China's involvement in Africa peace and security through the following lenses.

\subsection{China and Peacekeeping Missions}

For a long time, China's foreign policy was defined by a lack of international engagement and non-participation in multilateral organisation's peacekeeping initiatives. This remained China's stand until the 199os when China's policy towards peacekeeping started to shift away from Beijing's core belief of noninterference. Initially, Beijing was skeptical of the UN's peacekeeping role. The Chinese leadership then thought that the UN had been utilized for the Korean War in the early 1950s to legitimize and sanction actions that were viewed by China as aggressive military intervention (Ayenagbo et al., 2012: 24) in a situation where Chinese forces fought UN forces under a US command. Another reason for China's reluctance was driven by its belief that the sovereignty of nations gave them an inherent right to control their own affairs without intervention from third parties. This issue has been vital to the political survival of China in the post-World War II period (Rogers, 2007). The shift in China's policy was occasioned by Deng Xiaoping's move in the 1980's that allowed China to begin contributing towards the UN peacekeeping budget, and later allowed for the direct involvement of its personnel in peacekeeping missions. This was part of Xiaoping's sweeping economic reforms.

During the early stages of engagement in matters peace and security, China broadly adhered to traditional peacekeeping principles of impartiality and neutrality. Its participation in multi-dimensional peacekeeping operations had been limited to sending military observers and support, in the form of engineers, medical teams and logisticians in earlier operations, such as the UN's Advance Mission in Cambodia between October 1991 and March 1992. China's presence followed its participation in the Paris Peace Accords for Cambodia and diplomatic support for a peaceful transition and reconciliation government, which ended Cambodia's internal conflict that began after Vietnam's removal of the Khmer Rouge regime. However, the sending of its first active civilian police officers in East Timor UN mission from January 200o, marked a drastic shift in China's policy on peacekeeping. The deployment to East Timor underscored China's willingness to engage more actively in peacekeeping operations. 
There has been a dramatic surge in Chinese peacekeeping participation in the 21st Century, which reinforces Beijing's arrival as a major player on the world stage in general and UN peacekeeping missions in particular. China became a member of the UN Special Committee on Peacekeeping Operations in 1988 (Gill and Huang, 2013: 140-141) and from January 2001 to January 2009, the number of Chinese Blue Berets deployed to UN missions increased from less than 100 in 2000 to close to 2,000 in 2008 (UN Department of Peacekeeping Operations, 2001: 1; UN Department of Peacekeeping Operations, 2008: 1). In 2006, during a visit to South Africa, Chinese Foreign Minister Li Zhaoxing pledged Beijing's support for increased Chinese involvement in UN peacekeeping operations and for strengthening the role of the UN Security Council in authorising, managing and terminating peacekeeping operations (Shelton, 2008: 5). The recent increase in UN involvement has made China the thirdlargest contributor to the UN budget, the second highest contributor to the UN peacekeeping budget, and the 12th highest provider of peacekeepers, with 2,644 personnel as of 31st December 2017. According to the UN data on peacekeeping, China is the largest contributor of the permanent members of the Security Council. The personnel contribution is summarized in Table 2.

From the figures in Table 2, the paper infers that peacekeeping contributions have steadily become an important part of China's soft power strategy. It has allowed Beijing to advance its interests abroad while fostering collaboration with other nations, as it undergoes its so-called "peaceful rise". As noted by President Xi Jinping:

[China] will proactively push forward the construction of a global network of partners and will proactively push for political solutions for international hot issues and difficult problems (South China Morning Post, 1st December 2017).

TABLE 2 UN Security Council Members contribution to Peacekeeping Missions

\# Country Police UN Military Expert Troops Staff Officers Total

\begin{tabular}{|c|c|c|c|c|c|c|}
\hline 1. & China & $15^{6}$ & 28 & 2419 & 41 & 2644 \\
\hline 2. & France & 31 & 2 & 735 & 48 & 816 \\
\hline 3 . & United Kingdom & $\mathrm{o}$ & 5 & 647 & 27 & 679 \\
\hline 4. & Russia & 38 & 37 & o & 5 & 80 \\
\hline 5 . & USA & 7 & 3 & o & 45 & 55 \\
\hline
\end{tabular}

SOURCE: EXTRAPOLATED FROM UN DATA BASE 1ST JANUARY 2018 
By engaging in peacekeeping operations and by extension non-violent intervention and recourse to diplomacy, Beijing is attempting to balance out the perception of China as a threat. A significant increase in peacekeeping contributions took place in 2003 and 2004, which coincides both with its rising prominence as an economic power and the US invasion of Iraq. Therefore, the opportunity was seized to be seen as both a great power and ally to developing states (Institute for Security and Development Policy, 2018).

In Africa, China's footprints in peacekeeping has been noticeable. In fact, China's increased activity in peacekeeping missions in 2017 for example was in Africa. Out of the seven active peacekeeping missions in Africa, China has contributed 1839 troops. The troops are distributed as follows, 1036 troops in the UN Mission in the Republic of South Sudan (UnMISS), 421 troops in the UN Multidimensional Integrated Stabilization Mission in Mali (MINUSMA), 365 troops to the Africa Union/UN Hybrid Operation in Darfur (UNAmID), and 12 troops in the UN Mission for the referendum in Western Sahara (MINURSo). Through these missions, China has followed the wider trend in peacekeeping operations, which involves expanding the UN's limited military capabilities to include intelligence, drones, and attack helicopters to meet the asymmetrical warfare threat posed by non-state actors (Institute for Security and Development Policy, 2018). In Mali for example, the 421 Chinese troops consisted of three infantry platoons and armoured vehicles. Cabestan (2018) intimates that one of the objectives of the Chinese peacekeepers in Mali is to guard and protect the UN military camp in Gao. The Chinese involvement in Mali has attracted the wrath of non-state armed groups that have carried out dozens of mortar attacks on the Chinese base, and on 31 May 2016 for instance, one Chinese soldier was killed, and five others were injured when a vehicle-borne improvised explosive device was detonated. Accordingly, Chinese UN forces have adopted measures to improve camp security to protect their forces.

China's contribution to UNMISs became its largest ever and reached a strength of 1,061 troops and police in 2017. Already in January 2012, China had deployed a small infantry platoon to UNM ISs in order to protect its engineering and other staff in South Sudan (Large, 2016). This was another first for China, which had never before deployed a security unit. By 2016, China had three infantry companies in UNMISs, one of which was located in Juba with the mandate to secure the UN House, and with protecting a refugee camp of about 5,ooo people. The Chinese army had never before participated in protection of civilians (POC) or in force protection. China's deployment to South Sudan is unique in that among its personnel, it has deployed a combat battalion. 
Through this mission China has exported hard power (Etyang and Panyako, 2016: 5). The 1036 contingent troops in South Sudan are well equipped with armored infantry carriers, anti-tank missiles, mortars and drones.

\subsection{Military Cooperation}

China military cooperation with African countries gained momentum with the turn of the 21st Century. In 2015, President Xi Jinping pledged USD 100 million of military assistance to the AU and African countries. The military cooperation was recently cemented during the China-Africa Peace Forum that was held in July 2019. The forum was attended by approximately 100 delegates representing 50 African countries and the African Union. The delegation also included 15 defence ministers and chiefs of staff (China Daily, 2019). The high number of delegates alludes to the significance of the fraternal cooperation between China and African countries more specifically in the area of military cooperation. Suffice to mention that China, in its quest to foster and strengthen military cooperation, has embraced a comprehensive approach, blending commercial and trade deals with military related aspects such as training, arms sale and joint military drills. Through military cooperation, China aims at strengthening the capacity and the ability of African military units to respond to emerging security threats and challenges. Secondly, by supporting military units in Africa, China is able to secure its national interest without getting directly involved in the emerging security situations in the continent.

China has put in place different initiatives to concretise its military cooperation with African countries. Between 2003-2017 for instance, China loaned US $\$ 2.5^{2}$ billion to eight countries explicitly for military and national defence purposes (China Africa Research Initiative, 2019). Another US $\$ 1.36$ billion was loaned for policing, law and order programmes. Therefore, during this period African, countries had signed a total of UD $\$ 3.88$ billion $^{1}$ for military and domestic security purposes. Loans for defence and national security purposes encompass procurement of aircrafts, construction of military facilities, procurement of patrol ships, CCTV systems and other military hard wares (China Africa Research Initiative, 2019).

Through the loans, African countries have improved their defence capabilities, upgraded defence infrastructure and enhanced the welfare of military personnel. Of the 3.88 billion loan, Zambia had signed US\$ 1.42 billion, the highest amount in terms of defence and domestic security borrowing (China

1 These figures reflect only signed, implemented and completed loans as per the data curated by China-Africa Research Initiative. 
Africa Research Initiative, 2019). Zambia used part of the loans to build and improve barracks and housing for the military and other security personnel. The loans were also used to procure two MA 6o airliners and twelve Y-20 cargo planes. Other countries - Nigeria, Sierra Leone, Senegal, Uganda and Ghana have used the loans to establish national security communication and surveillance system (China Africa Research Initiative, 2019).

Despite the fact that the loans have been useful in strengthening Africa's military capabilities to some extent, China has been criticised for overburdening African countries with debt that they are currently struggling to repay. Most of them are debt trapped. Zambia for example has borrowed heavily and is now in high risk of debt stress. Nuanced anecdotal emerging from Zambia is that most of its strategic infrastructure such as the state-owned TV and radio station, the state electricity company Zesco and the new Lusaka international airport have been taken over by the Chinese due to the failure by the government to service its loans (Lusaka Times, 2018).

Secondly, some of the loans meant for military and national security purposes are mostly kept secret. The high level of secrecy involving these loans has provided room for corruption. Government officials have been accused of misusing the loans for personal aggrandisement. As a result, many countries' debts are growing without seeing a significant benefits and improvement in citizens general wellbeing. Thirdly, China has been accused of selling relatively low end and low technology equipment to African countries. A majority of the thirty Armoured Personnel Carriers (APC) that Kenya procured from China in 2015 for example, have been destroyed by improvised explosive device (IED) attacks orchestrated by Al-Shaabab terrorist group in Northern Kenya. Fourth, some of the security equipment supplied by China, have been used to suppress dissent and subdue the opposition in some countries thus eroding democratic consolidation. Taylor and Zhengyu Wu (2013:467) report that China supplied water cannons to the security institutions in Zimbabwe that have been used to subdue opposition protestors. In addition, China supplied a bugging machine that has been used to monitor and track cell phone communication of

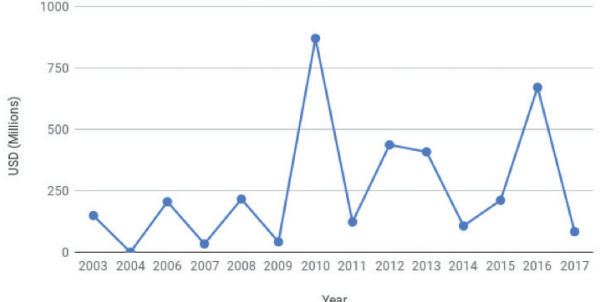

Year
FIGURE 1

Loans for defence and domestic security purposes (US\$ millions) SOURCE: CHINA AFRICA RESEARCH INITIATIVE (2019) 
opposition leaders. Such undemocratic acts rarely attract condemnation from the government of China.

China military cooperation has further been strengthened through capacity building programmes. During the China-Africa Summit held in 2015 in South Africa, China government officials underscored the centrality of capacity building in strengthening and maintaining peace and security. In his speech president Xi Jinping remarked that:

China stands ready to take an active part in Africa's efforts in capacitybuilding for maintaining and strengthening peace and security and support Africa in its endeavours to speed up development, eradicate poverty and realize durable peace.

On the basis of its military professionalisation programme, China has invited thousands of Africa military and security personnel for workshops and knowledge exchange visits. During the visits, participants tour various military facilities and establishments. Africa has also sent military attaches to China for learning expeditions. Joint drills and live-fire military exercises have been conducted in conjunction with the Chinas Peoples Liberation Army, Navy and Air Force. The exchange visits and joint military activities underscore the growing military ties between China and Africa and the concerted efforts towards deepening professional networks. In peacekeeping missions, Benabdallah (2016: 25) argues that Chinese peacekeepers have been asked by peacekeeping academy officials in Beijing to train "local security forces in confidence building measures, problem-solving techniques, among other peaceful conflict resolution strategies". While the visits, trainings and joint drills are critical in strengthening cooperation between China and Africa, we argue in this paper that China uses such ventures to project its military might and military culture. In addition, China uses the training to test new ideas, new technology, new equipment and new strategies. China also uses the joint military drills to keep its military busy and also to test their capabilities.

Military cooperation between China and Africa has also been manifested through arms trade. According to the Stockholm International Peace Research Institute (SIPRI), China's arms trade surged from US $\$ 650$ million in 2008 to US $\$ 1.13$ billion in 2017 (Tian et al., 2019: 5). 21 percent of this (approximately US 3 billion) was supplied to African countries. North African countries are the major importers of Chinese weapons representing 75 percent of the market share of Chinese exports to Africa. 29 percent is shared among Eastern African Countries while the balance of 29 percent is distributed among other 


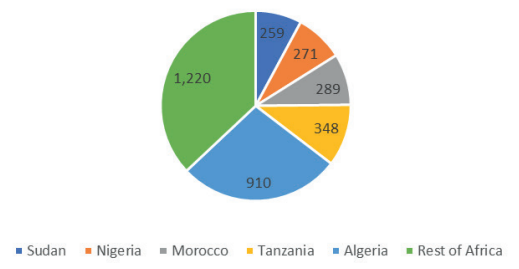

FIGURE 2

China's arms export to Africa

(2008-2017) in US\$ millions

SOURCE: STOCKHOLM

INTERNATIONAL PEACE RESEARCH

INSTITUTE (SIPRI)

countries. The top importers of Chinese weapons in North Africa include Algeria, Libya, Morocco and Tunisia (Tian et al., 2019: 7).

China's arms trade cooperation with African countries has been criticised on the basis that it has led to arms proliferation. The proliferation of arms has adversely contributed to sustained violent conflicts in various regions in the continent. Chinese weapons have been used in some of these conflicts. In Democratic Republic of Congo (DRC), specifically in the Eastern region, there have been numerous accounts that Chinese small arms and light weapons have been used by negative forces such as the Mai Mai to orchestrate violence. Amnesty International (2006) reported that Chinese weapons such as the AK 47 were common among soldiers and militia groups operating in Kivu province and parts of Ituri district. The AK 47 have been used to commit atrocities. According to a UN report, a Chinese company had supplied weapons and military materials to the Armed Forces of the Democratic Republic of Congo (FARDC). As noted in the report:

The Group observed that some FARDC troops deployed across the country had new equipment, including new fatigues and weapons. The Group started collecting information on their origin and determined that, in October 2017, there had been a delivery to the Congolese Government of military materiel, including military helmets, bulletproof vests, military boots and uniforms. The Group obtained information that China Xinxing Shanghai Import and Export Corporation had delivered some of the military materiel at the port of Matadi (UN report, 2018: 34)

The Conflict Armament Research (2018) has also documented incidences where Chinese weapons though supplied legally, have been used by both government and militia groups to cause atrocities in South Sudan. The Conflict Armament Research (CAR) affirms that 27 million rounds of small calibre ammunition transferred to the SPLA from China have sustained SPLA military offensive in South Sudan (CAR, 2018: 17). Chinese ammunitions were used by SPLA for instance in an attack on the Zande residential area of Ikpiro in Yambio and on the attack on the UN protection of civilians site in Malakal. 


\subsection{Conflict Resolution}

China's foreign policy objectives and practice have recently been anchored on mediation diplomacy aimed at conflict resolution. This has emerged as one of the central pillars that Beijing is deliberately using to position itself as a world peacemaker. The main argument is that China's conflict resolution role is part of a carefully devised strategy that suits the country's non-intervention policy. As noted by Chaziza (2018), China is becoming more deeply and more proactively involved diplomatically, seeking to shape the political and security developments in the world and more specifically in Africa. Thus, the role of peace broker is a 'legitimate way' to intervene in the domestic politics of other states without departing from its traditional guiding principle, and to promote or to secure its own economic interests and political influence in the region.

According to Qian and Wu (2009: 79-96), China's conflict resolution strategy is characterised by extreme flexibility of role-playing. China still adheres to its non-intervention principles and thus keeps a low, cautious profile in Africa internal affairs. Nevertheless, despite the official policy agenda, there has recently been a noticeable rise in Chinese mediation activities in the region that are geared towards conflict resolution. Such activities are visible in the economic field, and at the bilateral or multilateral diplomatic levels. China's mediation effort in regional hotspots offers important insights into how China's conflict resolution diplomacy has become more proactive and interventionist today, while formally continuing to adhere to the principle of non-intervention.

China got actively involved in the armed conflict in the Darfur region from its outbreak in 2003 until its end in 2009. This was a conflict that occurred when the Sudan Liberation Movement (SLM) and the Justice and Equality Movement (JEM) rebel groups began fighting the government of Sudan, which they accused of oppressing Darfur's non-Arab population. Many institutions and scholars have extensively written about China's involvement in this conflict (see, for example, Ahmed, 2010; Huang, 2007; Agubamah, 2014; Manyok, 2016). With this extensive research on Darfur, this paper deliberately shifts the focus to China's involvement in South Sudan.

China's proactive approach to South Sudan for instance appears to be a significant departure from its longstanding principle of non-interference (An, 2012). In fact, despite official rhetoric suggesting an unchanging doctrine, China's interpretation of non-interference has evolved in a way that mirrors that of its definition of national interests and objectives (Cui, 2012). Even as the theoretical debate continues, Beijing has charted a middle path maintaining the broad non-interference principle while stretching its interpretation and experimenting with various ways of applying it especially in the South Sudan case. 
After the 2005 peace agreement, when it appeared likely South Sudan would gain independence, the government of People's Republic of China through the China National Petroleum Corporation (CNPC) deepened its engagement with Juba, at first secretly, for fear of offending Khartoum (International Crisis Group, 2016). But CNPC and its partners found building relations with South Sudan challenging. Juba drove a hard bargain when it came to restructuring contracts and the volatile political environment undercut production. Chinese officials debated whether to leave or stay in South Sudan. It was observed that a withdrawal would mean leaving oil fields and other investments behind, likely to be damaged by war. It would also mean forfeiting economic and political leverage to influence events within South Sudan and the region. Beijing was also driven by "a sense of responsibility" to preserve South Sudan's economic future, which lives or dies with the oil industry (ICG, 2016). China, through diplomatic overtures opted to actively engage in conflict resolution initiatives in South Sudan through its envoy. Zhong Jianhua, who replaced Liu as Special Representative on African affairs in 2012, arrived in Nairobi as IGAD launched its mediation process. In response to IGAD's request for China's engagement, Beijing stepped up its involvement. Between 2014 and the signing of a peace agreement in August 2015, China was consistently engaged and supportive of the mediation process. Leveraging its longstanding ties with the Sudanese government, Beijing sent Foreign Minister Wang Yi to convene a "special consultation meeting" in Khartoum that included South Sudan's warring parties, Ethiopia, Sudan and IGAD.

Through the consultation meeting, China sent a message to the Sudanese government that supporting conflict in South Sudan would go against Chinese interests. The special consultation made IGAD refocus its attention and added new momentum to the peace process. Chinese influence encouraged Khartoum to exercise restraint in South Sudan, which also helped set the Sudanese government up in 2016 for its negotiations over sanctions relief from Washington, which was counselling the same approach. Beijing considered this a "ground-breaking" initiative aimed at resolving the perennial conflict in South Sudan. Zhong Jianhua, a Special Representative of the Chinese government on African affairs confirmed in his interview with the ICG that it was the first time that Beijing was calling upon leaders of countries in the region to discuss conflict resolution in another country (ICG, 2016).

China also combined mediation with power politics, exercising its economic preponderance in South Sudan and leveraging on the asymmetrical relations between the two countries to achieve its objectives. To enhance its mediation efforts in South Sudan, China promptly appointed a special envoy, Zhong Jianhua, a diplomat considered to have extensive knowledge of Sudan and 
South Sudan. In a statement, foreign ministry spokeswoman Hua Chunying said: "On behalf of the Chinese government, special envoy Zhong Jianhua is currently visiting South Sudan and neighbouring countries, and actively carrying out mediation efforts. China is willing to continuously enhance communication and coordination with all the relevant parties and jointly push for restoration of stability in South Sudan" (Voice of America, 2013). As a result of the negotiations, the first ceasefire agreement between South Sudan's warring parties was signed. However, it was noted by Harry Verhoeven that "Chinese diplomats took unprecedented steps in publicly pressuring belligerents Salva Kiir and his former vice president, Riek Machar, to sign a ceasefire agreement" (Verhoeven, 2014).

The Chinese government also operates a secondary support role premised on the principle of assistance especially in post conflict situations with a view of ameliorating the impact of conflicts to the population. These efforts are channelled through the affected governments and/or through support to regional organisations or national organisations. Examples include a Chinese government donation of US $\$ 300,000$ to the Kenyan Red Cross in January 2008 for support to post-election programmes, or its donation of US $\$ 300,000$ to the AU to assist with peacekeeping in Somalia in August 2007. The Chinese government has not proactively sought to involve itself in peace processes; rather, it has affirmed the primary responsibility of the international community and engaged as and when its interests have been threatened.

\subsection{Post-Conflict Reconstruction}

The post-conflict initiatives by China have partly been implemented through the high-profile Belt and Road Initiative (BRI), whose project selection has been marked by very high-risk tolerance and thus has seen billions of public and private capitals invested into conflict and post-conflict societies. Since infrastructure investments take a long time to amortise, Chinese investors will have a massive stake in the long-term stability of these countries, and this will oblige the Chinese government to safeguard its interests through conflict mediation measures. This will in turn engage China more deeply in conflict-prone environments and serve as a test case for whether peace and reconciliation can really spring from new economic opportunities.

China's Africa relations feature notable engagement in areas of ongoing conflict and in different contexts of states seeking to establish peace and promote development. There is no uniform and consistent engagement in postconflict reconstruction; nor is there any apparent dedicated and developed policy. China's role appears to be context dependent and ad hoc, blending business entrepreneurialism with government diplomacy (Large, 2011). Her 
engagement in post-conflict reconstruction has been predominantly economic but supplemented by a more involved political role. Emphasis on the economy and role of development in peacebuilding displays a self-reinforcing logic: economic development can overcome causes of conflict, and China is in a good position to support economic development.

The economic engagement is China's main approach towards post-conflict reconstruction. Chinese scholar Zhang Chun illustrates this in the example of China's engagement in South Sudan, explaining that right after South Sudan's independence in 2011, China has accentuated its standard "development-first diplomacy" focusing on South Sudan's socioeconomic development and reconstruction after independence (Zhang, 2015). In addition to South Sudan, China has been involved in post-conflict reconstruction in Angola, Liberia, DRC, and Sierra Leone among others.

Looking at the cases of Sudan, Angola, DRC or Libya, some of which are considered the typical examples of an alternative to liberal peacebuilding, the intention and the usefulness of Chinese engagement is hard to interpret. In Sudan, the Comprehensive Peace Agreement (CPA) was identified as an opportunity for projects of commercial nature which were started by many Chinese companies, both those already present in Sudan and new ones. While their activities were not named as post-conflict reconstruction, some argue that this could be interpreted as an effort to support peace (Large, 2012). In both the cases of Angola and DRC, the resource for infrastructure investment contracts, which are often interpreted as an alternative to the financing of the International Monetary Fund and the World Bank, are also a very convenient way to ensure against the problem of political risk from a purely business perspective. With this in mind, it is important to consider that China's emphasis on economic development as a way to create and maintain sustainable peace in fragile regions may be a way to frame their past and present economic activities as post-conflict reconstruction initiatives.

\section{4 Conclusion}

This paper sought to interrogate China's footprints in peace and security in Africa. The paper has demonstrated that Chinese interests in Africa's peace and security agenda is driven by geo-political interests and China's interest to project itself as an important actor in maintaining and promoting world peace. The paper has further demonstrated that China's role in Africa peace and security has been amplified in the area of peacekeeping. China has deployed a significant number of its officers (military, police and experts) in 
peacekeeping missions in Africa. The majority of African governments also enjoy low cost weapons from China which have mostly been used to enhance national security and secure regimes, especially where western governments are reluctant to sell the arms to them. However, the propensity to purchase cheap arms from China tend to exacerbate conflicts in Africa. China is becoming sensitive to the emerging talks that its arms sale to Africa has been fuelling conflicts in the continent. To ameliorate this, China has been discouraging the use of its weapons in war zones as was demonstrated in Darfur where China applied stringent criteria in exporting weapons to Sudan in 2007. While the cooperation between Africa and China in the area of peace and security seems to be mutually beneficially, African governments need to collectively define their interest in such a way that ensures maximum benefit from the cooperation. This can be achieved through collective decision making under the framework of the African Union. We predict that China's influence in Africa's peace and security will continue to grow as its economic interest expand.

\section{References}

Agubamah, E. (2014). The Darfur and China's African policy. International Journal of Humanities and Social Science, 4(11).

Aguirre, I. (2014). Violence in South Sudan threatens Chinese oil investment. OilPrice. com, Retrieved from http://oilprice.com/Energy/Crude-Oil/Violence-In-South -Sudan-Threatens-Chinese-Oil Investment.html.

Ahmed, G. K. (2010). The Chinese stance on the Darfur conflict. China in Africa Project: SAIIA Occasional Paper No. 67.

Alden, C. (2007). China in Africa. Zed Books.

Alden, C., \& Large, D. (2011) China's exceptionalism and the challenges of delivering difference in Africa. Journal of Contemporary China, 2o(68), 21-38.

Ayenagbo, K., Njobvu, T., Sossou, J. V., \& Tozounet, B. K. (2012). China's peacekeeping operations in Africa: From unwilling participation to responsible contribution. African Journal of Political Science and International Relations, 6(2), 22-32.

Barton, B. (2018). China's security policy in Africa. A new or false dawn for the evolution of the application of China's non-interference principle. South Africa Journal of International Affairs, 25(3), 413-434.

Benabdallah, L. (2016). China's peace and security strategies in Africa: Building capacity is building peace? African Studies Quarterly, 16(4), 17-34.

Buzan, B. (2010), China in international society: Is "peaceful rise" possible? The Chinese Journal of International Politics, 3, 5-36. 
Cabestan, J.-P. (2018). China's evolving role as a UN peacekeeper in Mali. United States Institute of Peace. Special Report 432, September 2018.

Chaziza, M. (2008). China mediation efforts in the Middle East and North Africa: Constructive conflict management. Strategic Analysis, 42(1), 29-41.

China Africa Research Initiative. (2019). Data: Chinese loans to Africa. Retrieved from http://www.sais-cari.org/data-chinese-loans-to-africa.

China Daily. (2011, February 28). 29,00o Chinese nationals pulled out of Libya.

China Daily. (2019, July 15). Overview of 1st China-Africa peace and security forum.

Voice of America. (2019, October 5). China sends envoy to South Sudan to push peace talks. Retrieved from http://www.voanews.com/content/reu-china-sends-envoysouth-sudan-push-peace-talks/1818388.html.

Conflict Armament Research. (2018). Weapon Supplies into South Sudan's Civil War. Conflict Armament Research Ltd.

Crisis Group interview, Zhong Jianhua, then special representative of the Chinese government on African affairs, Beijing, 8 March 2016.

Etyang, O., \& Panyako, S. O. (2016). China and Africa's peace and security agenda: The burgeoning appetite. Journal of African Conflicts and Peace Studies, 3(1), 1-22

Global Times (2011, March 4). China counting financial losses in Libya. Retrieved from http://www.china.org.cn/business/2011-03/o4/content_22051058.htm.

Hang, Z. (2014). China and South Sudan: Economic engagement continues amid conflict. Retrieved from http://africanarguments.org/2014/og/12/china-and-southsudan-economic engagement-continues-amid-conflict-by-zhou-hang/.

Holz, C. A. (2008). China's 2004 Economic Census and 2006 Benchmark Revision of GDP Statistics: More Questions than Answers? The China Quarterly.

Huang, C.-H. (2007). U.S. - "China Relations and Darfur". Fordham International Law Journal, 3r(4)

Huang, C., \& Gill, B. (2009). China's expanding peacekeeping Role. SIPRI. Retrieved from http://www.sipri.org/media/newsletter/essay/janog. Human Rights World Report 2014.

Institute for Security and Development Policy. (2018). China's Role in UN Peacekeeping: Backgrounder.

Large, D. (2011). China and Post-Conflict Reconstruction in Africa: The Case of Sudan. China in Africa Project, SAIIA Policy Briefing No. 36 (October 2011).

Large, D. (2012). Between the CPA and southern independence: China's post-conflict engagement in Sudan. South African Institute of International Affairs, Occasional Paper No. 115 (April 2012).

Large, D. (2016). China and South Sudan's Civil War, 2013-2015. African Studies Quarterly, 16(3-4), 35-54.

Large, D. (2017). China's role in the mediation and resolution of conflict in Africa. Paper presented at the os Lo Forum 2008 - The os Lo forum Network of Mediators, Oslo. 
Lusaka Times (2018, September 4). China to take over ZESCO - Africa Confidential. Retrieved from https://www.lusakatimes.com/2018/o9/o4/china-to-take-over -zesco-africa-confidential/.

Manyok, P. (2016). Oil and Darfur's blood: China's thirst for Sudan's oil. Journal of Political Sciences \& Public Affair, 4(1). doi:10.4172/2332-0761.1000189

Melvin, N. (2019). The Foreign Military Presence in the Horn of Africa Region. SIPRI.

Nantulya, P. (2019). Chinese Hard Power Supports Its Growing Strategic Interests in Africa. Africa Center for Strategic Studies.

Qian, C., \& Wu, X. (2009). The art of China's mediation during the nuclear crisis on the Korean Peninsula. Asian Affairs: An American Review, 36(2), 79-96.

Reuters. (2015, April 3). China evacuates foreign nationals from Yemen in unprecedented move.

Reuters (2020, April 6). Congo mine attack kills three Chinese nationals: Xinhua. Retrieved from https://www.reuters.com/article/us-china-congo-mining/congo -mine-attack-kills-three-chinese-nationals-xinhua-idUSKBN21OoV2.

Rogers, P. D. (2007). China and United Nations peacekeeping operations in Africa. Naval War College Review, 6o(2), 73-94.

Saferworld. (2010). China's Growing Role in African Peace and Security. Saferworld.

South China Morning Post (2017, December 1). China will take a more active role in world problems, Xi Jinping says.

Sun, Y. (2014). Africa in China's foreign policy. John L. Thornton China Center and Africa Growth Initiative.

Taylor, I., \& Wu, Z. (2013). China's arms transfers to Africa and political violence.Journal of Terrorism and Political Violence, 25(3), 457-475.

Tian, N., Fleurant, AS., Kuimova, A., Wezeman, P. D., \& Wezeman, S. T. (2019). Trends in World Military Expenditure, 2018. SIPRI.

United Nations. (2018). Final report of the Group of Experts on the Democratic Republic of the Congo. Retrieved from https://reliefweb.int/sites/reliefweb.int/ files/resources/N1812836.pdf.

Verhoeven, H. (2014). Is Beijing's non-interference policy history? How Africa is changing China. The Washington Quarterly, 37(2), 64.

Walsh, B. (2019). China's pervasive yet forgotten regional security role in Africa.Journal of Contemporary China, 28(120), 965-983. doi:10.1080/10670564.2019.1594107

Zhang, C., \& Kemple-Hardy, M. (2015). From Conflict Resolution to Conflict Prevention: China in South Sudan. CPWG briefing. Saferworld.

Zürcher, C. (2019). 30 years of Chinese peacekeeping. Centre for International Policy Studies, University of Ottawa. 